\title{
Effect of pregnancy and correlation of weight and heart rate with electrocardiographic parameters in the American Miniature Horse
}

\author{
[Efeito da prenhez e correlação do peso e frequência cardíaca com os parâmetros \\ eletrocardiográficos de equinos Mini-horse] \\ B.P. Santarosa ${ }^{1}$, M.L.G. Lourenço ${ }^{1}$, G.N. Dantas $^{1}$, C.M.V. Ulian ${ }^{1}$, M.C.T. Heckler ${ }^{1}$, \\ M.J. Sudano ${ }^{2}$, R.C. Gonçalves ${ }^{1}$, S.B. Chiacchio ${ }^{1}$ \\ ${ }^{1}$ Faculdade de Medicina Veterinária e Zootecnia - Universidade Estadual Paulitsa - FMVZ-UNESP - Botucatu, SP \\ ${ }^{2}$ Universidade Federal dos Pampas - Faculdade de Medicina Veterinária - Uruguaiana, RS
}

\begin{abstract}
There are studies on electrocardiogram (ECG) in several breeds of horses, which highlights the growing importance of cardiology in this species. But few authors have addressed the influence of pregnancy on the cardiac physiology of the mare, and specifically, there are no studies on the Mini-horse breed, as well as no correlation of body weight (BW) and heart rate (HR) with electrocardiographic parameters in this breed. The aims of this study were to determine the effects of pregnancy on ECG parameters and to examine the relationships between these variables and body weight (BW) and heart rate (HR). A total of 203 animals were used, including 143 females (66 pregnant) and 60 males. Electrocardiographic examinations were performed by computerized electrocardiogram (TEB), and the parameters were evaluated in six leads in the frontal plane (Lead I, II, III, aVR, aVL and aVF) and base-apex (BA). BW was inversely proportional to HR, which in turn showed an inverse relationship with the duration of the P-wave and the PR and QT intervals. The P-wave amplitude (lead II) was higher in pregnant animals than in non-pregnant animals. The effect of reproductive status should be monitored by ECG throughout the entire gestational period. The 66 pregnant mares in this study were examined during the first third of their pregnancies, thus, few differences were observed between pregnant and non-pregnant animals.
\end{abstract}

Keywords: horse, body weight, cardiology, heart rate, pregnancy

\section{RESUMO}

Existem estudos sobre eletrocardiograma (ECG) em diversas raças de equinos, o que ressalta a crescente relevância da cardiologia nessa espécie. Porém, poucos autores abordaram a influência da gestação na fisiologia cardíaca da égua, e, especificamente, não há trabalhos sobre a raça Mini-horse, assim como não há correlação do peso vivo (PV) e frequência cardíaca (FC) com os parâmetros eletrocardiográficos nessa raça. O objetivo deste estudo foi estudar a influência da prenhez sobre os parâmetros eletrocardiográficos, além de verificar a correlação do PV e FC com essas variáveis. Utilizaram-se 203 animais dessa raça, hígidos, sendo 143 fêmeas (66 prenhes) e 60 machos. Os exames eletrocardiográficos foram realizados por eletrocardiograma computadorizado (TEB), e os parâmetros foram avaliados em seis derivações do plano frontal (I, II, III, aVR, aVL e aVF) e base-ápice. O PV foi inversamente proporcional à $F C$, que também mostrou relação inversa com a duração da onda $P$ e os intervalos PR e QT. Na derivação II, a amplitude da onda P foi maior nos animais prenhes do que vazios. No entanto, sugere-se que a influência do estado reprodutivo seja estudada de forma progressiva pelo acompanhamento de todo o período gestacional, visto que as 66 éguas estudadas se apresentavam no terço inicial da prenhez, portanto poucas diferenças foram observadas entre animais prenhes e vazios.

Palavras-chaves: equinos, cardiologia, frequência cardíaca, gestação, peso corporal

Recebido 27 de julho de 2015

Aceito em 15 de novembro de 2015

*Autor para correspondência (corresponding author)

E-mail: mege@fmvz.unesp.br 


\section{INTRODUCTION}

In recent decades, cardiology has gained significant importance in equine medicine, not only for the early diagnosis and treatment of diseases but also for establishing a prognosis regarding the athletic performance of an animal (Diniz et al., 2011; Pedersen et al., 2013).

Performed in association with a careful clinical examination of the cardiovascular system, an electrocardiogram (ECG) is essential for a complete cardiac evaluation and allows the recognition of disorders affecting cardiac impulse formation and conduction, the diagnosis of various arrhythmias, and the evaluation of the evolution of certain cardiac diseases (White and Rhode, 1974; Diniz et al., 2008). Moreover, ECG is a low-cost, complementary, non-invasive examination and is easily performed in the field (Fregin, 1982). However, different breeds of horses and dogs vary in size, which affects the standard electrocardiographic parameters, making it necessary to establish a specific pattern for each breed (Hilwig, 1977).

Organic alterations that affect cardiovascular function occur continually during the growth of an animal (Ferasin et al., 2010). This phenomenon also occurs during pregnancy, which is a physiological state characterized by highly adaptive changes. These changes include an increase in total blood volume and cardiac output associated with myocardial hypertrophy. Furthermore, during pregnancy, peripheral vascular resistance decreases, and uterine blood flow increases, which also affect the cardiac conduction system (Lamb et al., 2010; Blanco et al., 2012). These changes are observable by ECG, and some published studies have described the effects of reproductive status on ECG parameters in several breeds of horses, including Thoroughbred (Fernandes et al., 2004), Mangalarga (Vicenzi et al., 2000) and ponies (Rezakhani et al., 2010). Several authors have also related body weight $(\mathrm{BW})$ to ECG parameters in ponies (Buss et al., 1975; Lombard et al., 1984), jumping horses (Diniz et al., 2011) and animals of various breeds and ages (Schwarzwald et al., 2012). However, there have been no studies involving ECG examination of the American Miniature Horse breed.
Horses of the American Miniature Horse breed have the muscular and proportional conformation of a miniature horse according to the Brazilian Association of Breeders of the Mini Horse (2012). As a triple fitness breed, it has been used as a saddle horse, a draft horse, and a pet. The main advantages of this breed are the ability to house the animals in small spaces, a low maintenance cost, miniature size, strength, docility and rusticity, characteristics that have generated a significant increase in the popularity of this breed in Brazil.

Given the increasing population of the American Miniature Horse breed due to popularization in agricultural fairs and exhibitions as well as the differences in their physiology relative to those of large breeds, it is important to understand their electrocardiographic features. As organic adaptations occur throughout life and cardiovascular functioning might vary according to the characteristics and functions of different breeds, this study aimed to describe the effects of reproductive status on electrocardiographic parameters as well as the correlations of said parameters with the BW and heart rate (HR) of animals of the American Miniature Horse breed.

\section{MATERIALS AND METHODS}

A total of 203 horses of the American Miniature Horse breed were evaluated, including 143 females and 60 males between 15 days and 21 years of age and weighing an average of $116.95 \pm 33.62 \mathrm{~kg}$.

This study was approved by the Ethics Committee on Animal Use (CEUA) of the School of Veterinary Medicine and Animal Science (FMVZ) of São Paulo State University (UNESP), Botucatu Campus (number 094/2012 CEUA).

Prior to the study, all of the animals were subjected to a thorough clinical examination consisting of a general physical examination (evaluation of visible mucosa, determination of the degree of hydration and capillary refilling time, palpation of the lymph nodes and the arterial pulse, measurement of the heart rate and respiratory frequency, evaluation of intestinal motility and the discharge of the ileocecal valve and measurement of rectal temperature) and an evaluation of the animal's history (issues 
pertaining to any current clinical symptoms, previous diseases and pregnancy history). The group included 66 pregnant females $(46.15 \%$, 66/143) at gestational stages between 2 and 5 months. All of the animals were evaluated for the presence of heart disease during the physical examination and by cardiac auscultation and were found to be healthy. The main exclusion criterion for this study was the presence of altered cardiac auscultation signs, such as a cardiac murmur or arrhythmia.

To obtain the electrocardiograms, we used a computerized device equipped with an ECG Acquisition Module for Computer, PC-ECG version 2.0 (Tecnologia Eletrônica Brasileira Ltda., São Paulo-SP, Brazil). The recording was performed using a halter with the animals restrained on floor plates coated with rubber to avoid interference with the electrocardiographic tracing. The animals were maintained in the station in standing position with limbs parallel to each other and without sedation, tranquilizers or anesthesia. ECG tracing was performed sequentially on each horse from leads in the frontal plane (I, II, III, aVR, aVL and aVF), with the right and left thoracic electrodes positioned above the olecranon and the right and left pelvic electrodes positioned above the patellar ligaments on the cranial face of each limb.

For the bipolar base-apex lead system, the electrodes were positioned with the yellow electrode on the left side above the cardiac apex immediately behind the olecranon and the red electrode on the right side, cranial to the scapula and near the jugular vein, with the ground electrode attached to the withers (Patteson, 1996).

Traces were obtained at a rate of $50 \mathrm{~mm} / \mathrm{second}$, with the sensitivity set to $1 \mathrm{~cm}=1$ millivolt $(\mathrm{mV})$ per minute, to analyze at least 10 complexes per electrocardiogram. For each electrocardiographic recording, the respiratory frequency, HR, morphology and duration of the $\mathrm{P}, \mathrm{R}$ and $\mathrm{T}$ waves, QRS complex, PR and QT intervals (seconds), amplitude of the $\mathrm{P}, \mathrm{R}, \mathrm{T}$ and $\mathrm{S}$ waves $(\mathrm{mV})$ and the ST segment (normal, elevated or depressed and unevenness) and polarity of the $\mathrm{T}$ wave (positive, negative or biphasic) were obtained using all seven leads. The mean cardiac electrical axis, expressed in degrees, was obtained using leads I and III.
This study consisted of two experiments. In the first experiment, the effects of pregnancy on the electrocardiographic parameters were evaluated. For the statistical analysis, the dependent variables of the cardiac parameters (HR; duration of the $\mathrm{P}$ and $\mathrm{T}$ waves, the PR and QT intervals and the QRS complex, in seconds; the amplitude of the P, R, S and T waves, in millivolts; and the axis, in degrees) were analyzed using ANOVA followed by the Tukey test using the PROC GLM program within SAS software (Statistical Analysis System Institute Inc., Cary, NC, USA). The sources of variation in the model included reproductive status (pregnant or not pregnant) and the first-order interactions; all of the effects were considered fixed. The animals were assumed to be a random effect. If the ANOVA revealed significant differences, the mean values were separated using Least Significant Difference (LSD). The data are presented as the mean values of the least squares and the standard errors.

In the second experiment, the relationships between the cardiac parameters and the weight and HR of the animals were evaluated. Pearson correlations between the values of different parameters were calculated using the PROC CORR program (Statistical Analysis System Institute Inc., Cary, NC, USA). A significance level of $5 \%(\mathrm{P}<0.05)$ was used in all analyses.

\section{RESULTS}

The weight of the 203 horses of the American Miniature Horse breed ranged from 10 to $190 \mathrm{~kg}$. Females accounted for the majority of the animals in this study, comprising $70.45 \%$ $(143 / 203)$ of the study population, whereas males comprised only $29.55 \%(60 / 203)$. The average live weight of the females was $121.61 \pm 31.10 \mathrm{~kg}$, and of the males was $105.83 \pm 36.94 \mathrm{~kg}$.

Physical examination of the animals revealed normal vital parameters. The cardiac auscultation findings were normal for all of the horses, with no crackles, murmurs or arrhythmias detected.

The mean HR of the 203 animals was $63.61 \pm 18.69 \mathrm{bpm}$. The pregnant females had a mean HR of $60.5 \pm 1.9 \mathrm{bpm}$, and the non-pregnant females had a mean HR of $63.2 \pm 1.8 \mathrm{bpm}$; the between-group difference was not significant $(\mathrm{P}=0.34)$. 
The mean cardiac axis of the pregnant mares was $71.1 \pm 12.5^{\circ}$, while that of the non-pregnant mares was $65.1 \pm 11.6^{\circ}$; these values were also not significantly different $(\mathrm{P}=0.72)$.

The predominant rhythm in both sexes was sinus tachycardia, which occurred in $43.33 \%(26 / 60)$ of the males and $62.94 \%(90 / 143)$ of the females. Sinus arrhythmia occurred in $35 \%(13 / 60)$ of the males and $11.19 \%(16 / 143)$ of the females. A normal sinus rhythm was present in $21.67 \%$ $(21 / 60)$ of the males and $23.08 \%(33 / 143)$ of the females. Only $2.80 \%(4 / 143)$ of the females exhibited sinus bradycardia. Two 13-month-old females showed sinus arrhythmia with a wandering pacemaker. An18-month-old male showed sinus arrhythmia and "sinus arrest".

Most of the animals (95\%) displayed a single positive P-wave. The predominant morphologies of the QRS complex were Qr, QRS, qR and QS.
A normal unevenness in the ST segment was observed in $96.06 \%(195 / 203)$ of the animals, whereas the remainder showed a depression of the amplitude between 0.05 and $0.1 \mathrm{mV}$.

The effects of pregnancy on the electrocardiographic parameters were evaluated in 66 mares of the American Miniature Horse breed (Tables 1 and 2). The following significant differences were observed: in the lead II, the amplitude of the P-wave was higher in the pregnant mares than in the non-pregnant mares $(\mathrm{P}=0.020)$; in the aVF lead $(\mathrm{P}=0.0073)$ and the $\mathrm{BA}$ lead $(\mathrm{P}=0.0058)$, the duration of the $\mathrm{P}$-wave was longer in the pregnant mares than in the nonpregnant mares; and in the aVR lead, the amplitude of the R-wave was higher in the nonpregnant mares relative to the pregnant mares $(\mathrm{P}=0.020)$.

Table 1. Duration of the P and T waves, QT and PR intervals, and the QRS complex in seconds (sec) as determined by electrocardiographic examinations of pregnant and non-pregnant mares of the American Miniature Horse breed using seven leads

\begin{tabular}{|c|c|c|c|c|c|c|}
\hline Lead & $\begin{array}{l}\text { Reproductive } \\
\text { status }\end{array}$ & $\mathrm{P}(\mathrm{sec})$ & PR (sec) & QRS (sec) & QT (sec) & $\mathrm{T}(\mathrm{sec})$ \\
\hline \multirow{3}{*}{ I } & Pregnant & $0.070 \pm 0.002$ & $0.161 \pm 0.003$ & $0.060 \pm 0.001$ & $0.378 \pm 0.006$ & $0.113 \pm 0.002$ \\
\hline & Not pregnant & $0.068 \pm 0.001$ & $0.160 \pm 0.003$ & $0.063 \pm 0.001$ & $0.367 \pm 0.005$ & $0.111 \pm 0.002$ \\
\hline & P-value & 0.67 & 0.83 & 0.20 & 0.18 & 0.40 \\
\hline \multirow{3}{*}{ II } & Pregnant & $0.075 \pm 0.002$ & $0.162 \pm 0.003$ & $0.057 \pm 0.003$ & $0.374 \pm 0.006$ & $0.109 \pm 0.003$ \\
\hline & Not pregnant & $0.070 \pm 0.002$ & $0.163 \pm 0.003$ & $0.054 \pm 0.003$ & $0.365 \pm 0.005$ & $0.103 \pm 0.003$ \\
\hline & p-value & 0.20 & 0.87 & 0.52 & 0.28 & 0.42 \\
\hline \multirow{3}{*}{ III } & Pregnant & $0.070 \pm 0.001$ & $0.164 \pm 0.003$ & $0.066 \pm 0.001$ & $0.375 \pm 0.006$ & $0.095 \pm 0.002$ \\
\hline & Not pregnant & $0.070 \pm 0.001$ & $0.165 \pm 0.002$ & $0.067 \pm 0.001$ & $0.369 \pm 0.005$ & $0.094 \pm 0.002$ \\
\hline & p-value & 0.87 & 0.90 & 0.59 & 0.52 & 0.85 \\
\hline \multirow{3}{*}{ aVR } & Pregnant & $0.065 \pm 0.002$ & $0.158 \pm 0.003$ & $0.060 \pm 0.001$ & $0.377 \pm 0.006$ & $0.114 \pm 0.002$ \\
\hline & Not pregnant & $0.064 \pm 0.001$ & $0.155 \pm 0.003$ & $0.061 \pm 0.001$ & $0.367 \pm 0.005$ & $0.113 \pm 0.002$ \\
\hline & p-value & 0.53 & 0.58 & 0.72 & 0.22 & 0.86 \\
\hline \multirow{3}{*}{$\mathrm{aVL}$} & Pregnant & $0.067 \pm 0.002$ & $0.153 \pm 0.003$ & $0.061 \pm 0.001$ & $0.376 \pm 0.006$ & $0.104 \pm 0.002$ \\
\hline & Not pregnant & $0.067 \pm 0.001$ & $0.162 \pm 0.003$ & $0.064 \pm 0.001$ & $0.367 \pm 0.005$ & $0.101 \pm 0.002$ \\
\hline & p-value & 0.96 & 0.08 & 0.22 & 0.28 & 0.45 \\
\hline \multirow{3}{*}{$\mathrm{aVF}$} & Pregnant & $0.076 \pm 0.001^{\mathrm{a}}$ & $0.167 \pm 0.003$ & $0.061 \pm 0.001$ & $0.371 \pm 0.006$ & $0.089 \pm 0.002$ \\
\hline & Not pregnant & $0.069 \pm 0.001^{b}$ & $0.163 \pm 0.003$ & $0.061 \pm 0.001$ & $0.370 \pm 0.006$ & $0.091 \pm 0.002$ \\
\hline & p-value & 0.0073 & 0.35 & 0.87 & 0.88 & 0.71 \\
\hline \multirow{3}{*}{ BA } & Pregnant & $0.085 \pm 0.001^{\mathrm{a}}$ & $0.178 \pm 0.003$ & $0.089 \pm 0.007$ & $0.391 \pm 0.006$ & $0.115 \pm 0.002$ \\
\hline & Not pregnant & $0.077 \pm 0.001^{\mathrm{b}}$ & $0.175 \pm 0.003$ & $0.078 \pm 0.006$ & $0.398 \pm 0.006$ & $0.122 \pm 0.002$ \\
\hline & p-value & 0.0058 & 0.46 & 0.26 & 0.45 & 0.08 \\
\hline
\end{tabular}

Different superscript letters in the same column indicate significant differences $(\mathrm{P}<0.05)$. 
Table 2. Amplitudes of the $\mathrm{P}, \mathrm{R}$ and $\mathrm{T}$-waves in millivolts $(\mathrm{mV})$ as determined by electrocardiographic examination of pregnant and non-pregnant mares of the American Miniature Horse breed using seven leads

\begin{tabular}{|c|c|c|c|c|}
\hline Lead & Reproductive status & $\mathrm{P}(\mathrm{mV})$ & $\mathrm{R}(\mathrm{mV})$ & $\mathrm{T}(\mathrm{mV})$ \\
\hline \multirow{3}{*}{ I } & Pregnant & $0.109 \pm 0.004$ & $0.114 \pm 0.01$ & $-0.521 \pm 0.03$ \\
\hline & Not pregnant & $0.104 \pm 0.004$ & $0.081 \pm 0.01$ & $-0.483 \pm 0.02$ \\
\hline & p-value & 0.44 & 0.15 & 0.37 \\
\hline \multirow{3}{*}{ II } & Pregnant & $0.175 \pm 0.004^{\mathrm{a}}$ & $0.197 \pm 0.018$ & $-0.961 \pm 0.43$ \\
\hline & Not pregnant & $0.160 \pm 0.004^{b}$ & $0.202 \pm 0.017$ & $-0.285 \pm 0.39$ \\
\hline & p-value & 0.02 & 0.85 & 0.25 \\
\hline \multirow{3}{*}{ III } & Pregnant & $0.125 \pm 0.004$ & $0.288 \pm 0.02$ & $0.203 \pm 0.03$ \\
\hline & Not pregnant & $0.128 \pm 0.004$ & $0.321 \pm 0.02$ & $0.172 \pm 0.02$ \\
\hline & p-value & 0.56 & 0.36 & 0.45 \\
\hline \multirow{3}{*}{ aVR } & Pregnant & $-0.129 \pm 0.003$ & $0.156 \pm 0.19^{\mathrm{a}}$ & $0.432 \pm 0.024$ \\
\hline & Not pregnant & $-0.122 \pm 0.003$ & $0.215 \pm 0.17^{\mathrm{b}}$ & $0.431 \pm 0.022$ \\
\hline & p-value & 0.14 & 0.02 & 0.96 \\
\hline \multirow{3}{*}{$\mathrm{aVL}$} & Pregnant & $0.015 \pm 0.01$ & $0.121 \pm 0.01$ & $-0.358 \pm 0.02$ \\
\hline & Not pregnant & $0.021 \pm 0.01$ & $0.095 \pm 0.01$ & $-0.338 \pm 0.02$ \\
\hline & p-value & 0.69 & 0.31 & 0.55 \\
\hline \multirow{3}{*}{$\mathrm{aVF}$} & Pregnant & $0.144 \pm 0.004$ & $0.216 \pm 0.020$ & $-0.025 \pm 0.032$ \\
\hline & Not pregnant & $0.143 \pm 0.004$ & $0.235 \pm 0.019$ & $-0.045 \pm 0.030$ \\
\hline & $\mathrm{p}$-value & 0.84 & 0.50 & 0.66 \\
\hline \multirow{3}{*}{$\mathrm{BA}$} & Pregnant & $0.253 \pm 0.006$ & $0.015 \pm 0.005$ & $0.258 \pm 0.05$ \\
\hline & Not pregnant & $0.236 \pm 0.006$ & $0.018 \pm 0.004$ & $0.267 \pm 0.05$ \\
\hline & $\mathrm{p}$-value & 0.07 & 0.66 & 0.90 \\
\hline
\end{tabular}

Different superscript letters in the same column indicate significant differences $(\mathrm{P}<0.05)$.

The Pearson's correlations between the electrocardiographic parameters determined using leads II and $\mathrm{BA}$ and $\mathrm{BW}$ and $\mathrm{HR}$ are shown in Table 3. Body weight was positively correlated with the duration of the $\mathrm{P}$-wave determined using all of the leads $(\mathrm{P}=0.0020$ for lead I, $\mathrm{P}=0.0008$ for lead II, $\mathrm{P}=0.0001$ for lead III and aVF; $\mathrm{P}=0.0006$ for aVR; $\mathrm{P}=0.0045$ for $\mathrm{aVL}$; and $\mathrm{P}=0.0007$ for $\mathrm{BA}$ ) and with the duration of the QT $(\mathrm{P}<0.0001$ for all of the leads) and $\mathrm{PR}$ intervals $(\mathrm{P}<0.0001$ for all of the leads $)$. Regarding the P-wave amplitude, only the values determined using the BA lead were positively correlated with $\mathrm{BW}$. The following positive correlations were identified: between BW and the R-wave amplitude determined using leads I $(\mathrm{P}=0.0443)$ and $\operatorname{aVL}(\mathrm{P}=0.0111)$; the duration of the $\mathrm{QRS}$ complex determined using leads III $(\mathrm{P}=0.003), \quad \mathrm{aVR} \quad(\mathrm{P}=0.0449) \quad$ and $\quad \mathrm{aVF}$ $(\mathrm{P}=0.0150)$; the duration of the $\mathrm{T}$ wave determined using leads III $(\mathrm{P}=0.0442)$ and $\mathrm{aVL}$ $(\mathrm{P}=0.0324) ; \quad$ and the $\mathrm{T}$-wave amplitude determined using leads III $(\mathrm{P}=0.0175)$ and aVF $(\mathrm{P}=0.0012)$. There were negative correlations between $\mathrm{BW}$ and the R-wave amplitude determined using leads III $(\mathrm{P}=0.0003)$, aVR $(\mathrm{P}=0.0070)$ and $\mathrm{aVF}(\mathrm{P}=0.0030)$ as well as the Twave amplitude determined using lead aVR $(\mathrm{P}=0.0029)$.

Negative correlations were found between HR and $\mathrm{BW}(\mathrm{P}<0.0001)$ determined using leads II ($0.39085)$ and BA (-0.33257) as well as between $\mathrm{BW}$ and the durations of the $\mathrm{P}$-wave $(\mathrm{P}<0.0001$ for II and $\mathrm{BA})$, the $\mathrm{T}$-wave $(\mathrm{P}=0.0322$ for II, $\mathrm{P}<0.0001$ for $\mathrm{BA})$ and the $\mathrm{PR}(\mathrm{P}<0.0001$ for II and $\mathrm{BA})$ and the $\mathrm{QT}$ intervals $(\mathrm{P}<0.0001$ for II and BA) determined using both leads. There was also a negative correlation between $\mathrm{HR}$ and the duration of the QRS complex determined using lead BA $(\mathrm{P}=0.0162)$. A positive correlation between HR and the cardiac axis was observed using lead II $(\mathrm{P}=0.0137)$. 
Table 3. Pearson's correlations (CR) of body weight $(\mathrm{BW} ; \mathrm{kg})$ and heart rate (HR; bpm) with the electrocardiographic parameters of animals of the American Miniature Horse breed $(n=203)$ observed using leads II and BA

\begin{tabular}{|c|c|c|c|c|c|c|c|c|c|c|}
\hline Lead & CR & $\begin{array}{c}\mathrm{P} \\
(\mathrm{sec})\end{array}$ & $\begin{array}{c}\mathrm{P} \\
(\mathrm{mV})\end{array}$ & $\begin{array}{c}\text { PR } \\
\text { (sec) }\end{array}$ & $\begin{array}{l}\text { QRS } \\
\text { (sec) }\end{array}$ & $\begin{array}{c}\mathrm{R} \\
(\mathrm{mV})\end{array}$ & $\begin{array}{l}\text { QT } \\
\text { (sec) }\end{array}$ & $\begin{array}{c}\mathrm{T} \\
(\mathrm{sec})\end{array}$ & $\begin{array}{c}\mathrm{T} \\
(\mathrm{mV})\end{array}$ & $\begin{array}{c}\text { Axis } \\
\text { (degree) }\end{array}$ \\
\hline \multirow{2}{*}{ II } & CR-BW & 0.23514 & 0.03517 & 0.37205 & 0.03869 & -0.11266 & 0.36996 & -0.0394 & 0.01121 & -0.12569 \\
\hline & p-value & 0.0008 & 0.6202 & $<0.0001$ & 0.5855 & 0.1113 & $<0.0001$ & 0.5743 & 0.8745 & 0.0754 \\
\hline BA & p-value & 0.0007 & 0.0276 & $<0.0001$ & 0.0791 & 0.4313 & $<0.0001$ & 0.8742 & 0.7369 & \\
\hline II & CR-HR & -0.38569 & 0.03367 & -0.56970 & -0.06763 & 0.17207 & -0.82589 & -0.15118 & 0.04301 & 0.17369 \\
\hline BA & p-value & $<0.0001$ & 0.3848 & $<0.0001$ & 0.0162 & 0.1795 & $<0.0001$ & $<0.0001$ & 0.9677 & - \\
\hline
\end{tabular}

\section{DISCUSSION}

Although significant differences in some of the ECG parameters (such as the P-wave amplitude determined using the lead II) were observed between the pregnant and non-pregnant mares, no significant differences in cardiac rhythm or other parameters were detected. This result is most likely due to the gestational period in which the pregnant females were evaluated (the initial third). A mild deviation of the cardiac axis to the right was previously reported in pregnant PSI horses, depending on the ability of the viscera to accommodate the increased abdominal pressure on the diaphragmatic dome (Fernandes et al., 2004). This feature was also observed in pregnant Mangalarga breed mares (Vicenzi et al., 2000). However, the gestational stage of the 11 PSI mares was unclear (Fernandes et al., 2004). One study examining the ECGs of ponies included nine pregnant females, but this group was not evaluated separately from the 14 males and the one non-pregnant female (Rezakhani et al., 2010). In this study, it was noted that the gestational period was a limitation in evaluating the effects of pregnancy on the electrocardiographic parameters because fetal growth affects the circulation and can alter the cardiac axis. It was therefore proposed that the pregnancies of the females be synchronized and that these animals be monitored during different periods of pregnancy.

The increase in the P-wave amplitude during pregnancy could be due to the major adaptive changes that occur in the cardiovascular system during pregnancy. However, it did not occur in the pregnant Creole mares studied by Pascon et al. (2015). The physiological changes that occur with pregnancy include increased blood volume and cardiac output, which are associated with myocardial hypertrophy, as well as decreased peripheral resistance and an increase in uterine vascular blood flow. With increased blood volume, the atrium is also dilated in a compensatory manner, thereby elevating the amplitude of the $\mathrm{P}$ wave. These anatomical and functional adaptations also affect the cardiac conduction system, resulting, in some cases, in an increase in the QT interval during pregnancy (Blanco et al., 2012). However, this effect was not observed in the horse breed examined in this study.

In pony foals evaluated by echocardiography from one to 90 days of age, BW was found to be correlated only with the dimensions of the cardiac chambers, with linear relationships between the weights of the growing foals and the internal dimensions of the left ventricle during diastole and systole and those of the right ventricle during diastole (Lombard et al., 1984). Other researchers have reported the average live weights of adult ponies (Buss et al., 1975) and jumping horses (Diniz et al., 2011) but did not correlate these values with electrocardiographic parameters, as was performed in this study.

The effects of BW on the HR and ECG parameters were previously evaluated in 250 animals of different equine breeds and physical sizes, with weights ranging from 46 to $1018 \mathrm{~kg}$ (Schwarzwald et al., 2012). These authors observed that the resting HR was significantly related to $\mathrm{BW}$ in horses, corroborating the data obtained in this study. However, the same authors classified the relationship between HR and BW as relatively weak. The absolute difference in the average HR was only 24 seconds in animals ranging from 400 and $700 \mathrm{~kg}$ in weight. However, this difference increased to 108 seconds when considering a larger weight 
range of 50 to $1000 \mathrm{~kg}$. Only $21 \%$ of the variation in HR can be explained by differences in $\mathrm{BW}$; the remaining $79 \%$ must be explained by other factors, including age, sex, temperament, athletic condition, and possibly breed. The authors concluded that there was a significant but weak inverse relationship between HR and BW (Schwarzwald et al., 2012), as was observed in this study. Thus, when observed on a population level, the small equine breeds, such as the American Miniature Horse, tend to have a higher HR compared with large breeds. Likewise, there was a significant but weak direct relationship between BW and the PQ, QRS, and QT intervals. In this study, there was also a significant positive correlation between BW and the duration of the QT interval. In turn, there was a negative correlation between HR and this interval, which is related to ventricular repolarization time (Pedersen et al., 2013). Therefore, as HR increases, the duration of ventricular repolarization is expected to shorten because the heart size should also be smaller, thus resulting in a QT interval that is shorter than that of an animal with a higher BW. The same phenomenon occurred with the PR interval, which reflects the time for atrial repolarization. The duration of the P-wave was also inversely proportional to the HR because it reflects the time required for atrial polarization; thus, this parameter is directly related to the size of the atrium. Accordingly, a smaller heart size corresponds to a higher $\mathrm{HR}$ and a shorter duration of the P-wave.

Pascon et al. (2015) studied 84 healthy Creole mares (34 pregnant and 50 non-pregnant) of three different ages. The authors demonstrated that age affected only QRS duration and that pregnancy was capable of decreasing the indexes of HR variability in the time domain, which could have influenced the electrocardiographic evaluation of the enrolled Creole mares.

\section{CONCLUSIONS}

This study demonstrated correlations of BW and HR with the ECG parameters of the American Miniature Horse determined using six leads in the frontal plane and base-apex. BW was inversely proportional to $\mathrm{HR}$, which also showed an inverse relationship with the duration of the Pwave and the PR and QT intervals. The effects of pregnancy on the parameters determined using all of the leads were evaluated, but few differences were observed, most likely because the mares were in the initial third of the gestational period. Nevertheless, the P-wave amplitude determined using lead II in pregnant mares was higher than that measured in nonpregnant mares. However, to obtain more reliable data, we propose that the effects of pregnancy on ECG parameters be studied according to specific monthly gestation stages, from the first to the eleventh month.

\section{ACKNOWLEDGMENTS}

The authors thank the owners of the following farms for their assistance: São Benedito/AvaréSP (José Bastos Cruz Sobrinho), Cabanha Guguiná/Lençóis Paulista-SP (Luís Santana Zillo), Jequitibá/Cerqueira César-SP (Marcelo Assumpção Serra), and Água Azul/Dois Córregos-SP (José Eden Matosinho).

\section{REFERENCES}

BLANCO, P.G.; BATISTA, P.R.; RE, N.E. et al. Electrocardiographic changes in normal and abnormal canine pregnancy. Reprod. Domest. Anim., v.47, p.252-256. 2012.

Mini-horse: características da raça. Associação dos Criadores de Equinos Mini-Horse, 2012. Disponível

em: $<$ http://www.ponei.com.br/arquivos_PDF/Hi storico_Ficha_Tecnica.pdf $>$ Acessado em: 17 mar. 2012 .

BUSS, D.D.; RWALINGS, C.A.; BISGARD, G.E. The normal electrocardiogram of the domestic pony. J. Electrocardiol. v.8, p.167-172, 1975.

DINIZ, M.P.; MICHIMA, L.E.S.; FERNANDES, W.R. Estudo eletrocardiográfico de equinos de salto sadios. Pesqui. Vet. Bras. v.31, p.355-361, 2011.

DINIZ, M.P.; MUZZI, R.A.L.; MUZZI, L.A.L. et al. Estudo eletrocardiográfico de equinos da raça Mangalarga Marchador. Arq. Bras. Med. Vet. Zootec. v.60, p.536-542, 2008.

FERASIN, L.; FERASIN, H.; LITTLE, C.J. Lack of correlation between canine heart rate and body size in veterinary clinical practice. J. Small Anim. Pract. v.51, p.412-418, 2010. 
FERNANDES, W.R.; LARSSON, M.H.M.A.; ALVES, A.L.G. et al. Características eletrocardiográficas em equinos clinicamente normais da raça Puro Sangue Inglês. Arq. Bras. Med. Vet. Zootec. v.56, p.143-149, 2004.

FREGIN, G.F. The equine electrocardiogram with standardized body and limb positions. Cornell Vet. v.72, p.304-324, 1982.

HILWIG, R.W. Cardiac arrhythmias in the horse. J. Am. Vet. Med. Assoc. v.170, p.153-163, 1977.

LAMB, A.P.; MEURS, K.M.; HAMLIN, R.L. Correlation of heart rate to body weight in apparently normal dogs. J. Vet. Cardiol., v.12, p.107-110, 2010.

LOMBARD, C.W.; EVANS, M.; MARTIN, L. et al. Blood pressure, electrocardiogram and echocardiogram measurements in the growing pony foal. Equine Vet. J., v.16, p.342-347, 1984.

PATTESON, M.W. Equine cardiology. Oxford: Blackwell Science, 1996.

PASCON, J.P.E.; SANTOS, F.P.; PEREIRA, D.T.P. et al. Estudo eletrocardiográfico de éguas da raça Crioula. Pesqui. Vet. Bras.v.35, p.319$323,2015$.
PEDERSEN, P.J.; KANTERS, J.K.; BUHL, R. et al. Normal electrocardiographic QT interval in race-fit Standardbred horses at rest and its rate dependence during exercise. J. Vet. Cardiol., v.15, p.23-31, 2013.

REZAKHANI, A.; PIRIE, R.S.; BLISSITT, K.J. Effects of age on the prevalence of cardiac dysrhythmias in ponies. Iran. J. Vet. Res., v.11, p.200-220, 2010.

SCHWARZWALD, C.C.; KEDO, M.; BIRKMANN, K., et al. Relationship of heart rate and electrocardiographic time intervals to body mass in horses and ponies. J. Vet. Cardiol., v.14, p.343-350, 2012.

VICENZI, R.C.; LARSSON, M.H.M.A.; FERNANDES, W.R. Parâmetros eletrocardiográficos de equinos clinicamente normais da raça Mangalarga. Parte II: eixo elétrico médio no plano frontal. Rev. Bras. Med. Vet., v.22, p.111-112, 2000.

WHITE II, N.A.; RHODE, E.A. Correlation of electrocardiographic findings to clinical disease in the horse. J. Am. Vet. Med. Assoc., v.164, p.46-56, 1974. 